Evaluation of Antimicrobial and Antioxidant activity of secondary metabolites isolated from endophytic bacterium Bacillus megaterium isolated from wheat root in Iraq

Rashid Rahim Hateet

\title{
Evaluation of Antimicrobial and Antioxidant activity of secondary metabolites isolated from endophytic bacterium Bacillus megaterium isolated from wheat root in Iraq
}

\author{
Rashid Rahim Hateet \\ College of pharmacy- University of Misan, Iraq
}

Received: 5 September 2015

Accepted: 19 May 2015

\begin{abstract}
$\underline{\text { Abstract }}$
The present study was carried out to find out the antimicrobial activity of endophytic bacteria isolated from wheat plant root by surface sterilization method. Bacterial strain was identified as Bacillus megaterium. Secondary metabolites was carried out by ethyl acetate solvent .Secondary metabolites were demonstrated for antimicrobial activity against Gram-:Negative Bacteria namely; Escherichia coli, Salmonella typhi and Pseudomonas aeruginosa which range between (16.5-31.0)mm and range between(29.5-33.0)mm against Gram-Positive Bacteria and antifungal activates tested against yeasts test namely; Candida albicans with inhibition zone $16.0 \mathrm{~mm}$ and $12.0 \mathrm{~mm}$ against Candida kruzi. Minimum inhibitory concentrations were in the range between (6.25-12.25) and (3.12-25.0) $\mu \mathrm{g} / \mathrm{ml}$ against Gram-Negative and Gram-Positive bacteria respectively and $(50) \mu \mathrm{g} / \mathrm{ml}$ against yeasts test and minimal bactericidal concentrations ranged from (12.5 to 25.0) $\mu \mathrm{g} / \mathrm{ml}$ and (6.12-50) $\mu \mathrm{g} / \mathrm{ml}$ against Gram-Negative and Gram- Positive bacteria respectively and minimal fungicidal concentrations (100) $\mu \mathrm{g} / \mathrm{ml}$ against yeasts. The antioxidant activity was analyzed using2,2-diphenyl-1-picrylhydrazyl (DPPH) scavenging assays have shown high rates of inhibition .A verification of non-toxicity of the bacterial secondary metabolites against human blood revealed a negative test. The metabolite produced by the endophytic bacteria could be an alternative source of antimicrobial and antioxidants.
\end{abstract}

Keywords: Antimicrobial activity, Antioxidant activity, Endophytic bacteria, bacteria. 
Evaluation of Antimicrobial and Antioxidant activity of secondary metabolites isolated from endophytic bacterium Bacillus megaterium isolated from wheat root in Iraq

\title{
Rashid Rahim Hateet
}

\author{
Bacillus تقييم الفعالية الضد ميكروبية والضدتأكسدية للايض الثانوي المعزول من بكتريا \\ megaterium المعزولة من النسيج الداخلي لجذور نبات الحنطة في العراق \\ كليه الصيدلة - جامعة ميبّ ريسان
}

\section{الخلاصة}

تضمنت الدر اسة الحالية عزل وتتخيص بكتريا. Bacillus megaterium من النسيج الداخلي لجذور نبات الحنطة المحلية

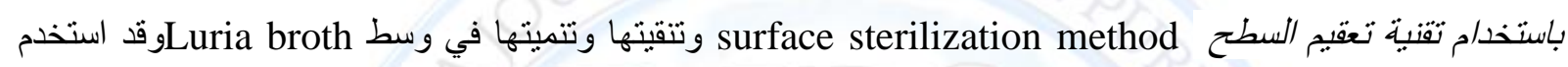
المذيب اثيل استيتethyl acetate للحصول على الايض الثانوي البكتيري والذي اختبرت فعاليته الضد ميكروبية تجاه Escherichia coli , Salmonella typhi,Pseudomonas ثلاثة عزلات بكتيريه سالبه لصبغة غرام تضدنت aeruginosa Bacillus cereus Streptococcus pneumonia, Staphylococcus aureus بين(29.5-33.0ملم وكذلك اختبرت الفعالية الضد فطريه تجاه نوعين من الخميرة تضمنت Candida albicans وبقطر تثبيط 16.0ملم وتجاه Candida kruzi وبقطر تثبيط 12.5 ملم باستخدام تقنيه الانتشار بالأقر اص .وتراوحت قيم التركيز

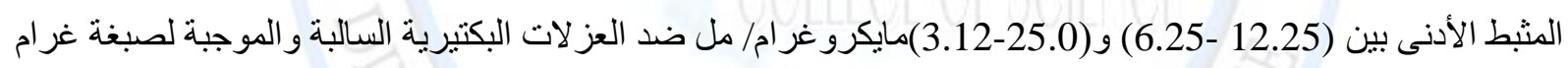

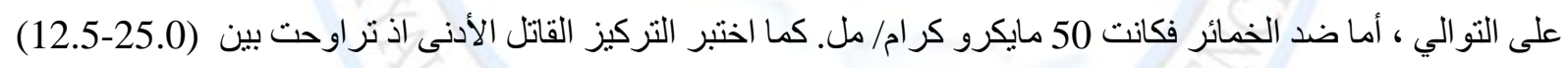

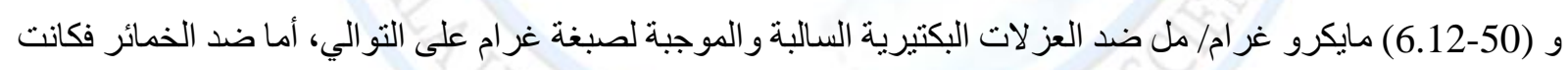

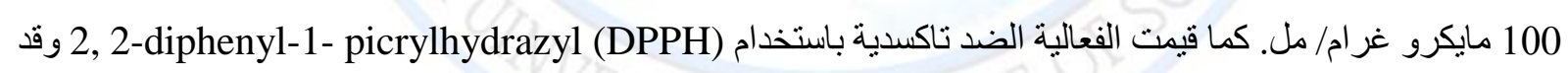
أظهرت نسب تثبيط عالية. كما اختبرت السمية الخلوية للايض الثانوي البكتبري والذي لم يظهر أي سمية تجاه كريات الدم الحمر عند التراكيز المختبرة أن الايض المنتج من بكتريا Endophytic يمكن أن تكون مصدرا بديلا جيدا للمضادات الميكروبية و التاكسدية الصناعية. الكلمات المفتاحية:الفعالية الضد ميكروبية، الفعالية الضد نأكسدية، بكتريا النابوت الداخلي، البكتريا. 
Evaluation of Antimicrobial and Antioxidant activity of secondary metabolites isolated from endophytic bacterium Bacillus megaterium isolated from wheat root in Iraq

\section{Rashid Rahim Hateet}

\section{$\underline{\text { Introduction }}$}

Plant-associated microorganisms fulfill important functions for plant growth and health. On the one hand, plants protect themselves by producing some compounds called secondary metabolites against pathogenic microbes. Some endophytic microorganisms produce antibiotics or growth-stimulating factor to benefit plant. Plant endophytes are microorganisms that live in the internal organs or cell gaps of healthy plants. Many factors, such as soil conditions and phytopathogen populations, influence the population structures of endophytic bacteria $(1,2)$. Endophytic bacteria have been isolated from the interior of the stems and roots of many plants, such as ginseng, cotton, sweet corn, canola, wheat, and others $(3,4)$. Microbes that inhabit asymptomatically in the living tissues of plants without causing any substantive negative effect are known as endophytic microbes (5). Each plant species that exists on earth is considered to be a host for one or more endophytes. Diversity also associated with the colonizing bacterial taxa (6). Many bioactive substances that endophyte produce were relatively new to us. Therefore there is a huge potential to screen novel, highly active and low toxicity antimicrobial compounds from endophytic microorganisms (7) Metabolites isolated from the endophytes are good sources of novel secondary metabolic products having diverse structural groups and showing antibacterial, antifungal, anticancer, antiviral, antioxidant, insecticide, antidiabetic and immunosuppressive activities $(8,9)$.Research on antibiotics and other microbial natural products is pivotal in the global fight against the growing problem of antibiotic resistance. It is necessary to find new antibiotics to tackle this problem $(10,11)$.

\section{$\underline{\text { Materials and Methods }}$}

\section{Plant selection and location}

Wheat plant was collected from different parts of South of Iraq from Missan city during the year 2015. The roots of plants were washed with tap water and processed for the isolation of endophytic bacteria. 
Evaluation of Antimicrobial and Antioxidant activity of secondary metabolites isolated from endophytic bacterium Bacillus megaterium isolated from wheat root in Iraq

\section{Rashid Rahim Hateet}

\section{Media preparation and growth conditions of microorganism}

The bacterial medium used in the isolation of endophytic bacteria contained the following: tryptone, $20 \mathrm{~g} / \mathrm{L}$; yeast extract, $5 \mathrm{~g} / \mathrm{L}$; trace salt $(1 \mathrm{~mL} / \mathrm{L}$ : FeSO4.7H2O, $0.01 \mathrm{~g} / \mathrm{L}$; $\mathrm{MnCl} 2 \cdot 4 \mathrm{H} 2 \mathrm{O}, 0.01 \mathrm{~g} / \mathrm{L} ; \mathrm{ZnSO} 4 \cdot 7 \mathrm{H} 2 \mathrm{O}, 0.01 \mathrm{~g} / \mathrm{L})$; glucose, $5 \mathrm{~g} / \mathrm{L}$; agar, $15 \mathrm{~g} / \mathrm{L}$; at pH 7.3.

\section{Isolation of endophytic bacteria}

Endophytic bacteria were isolated from Wheat plant roots from three different locations. The roots of Wheat plant were surface sterilized with $99 \%$ ethanol for $60 \mathrm{~s}$ followed by $3.125 \%$ sodium hypochlorite for $6 \mathrm{~min}$, washed in $99 \%$ ethanol for $30 \mathrm{~s}$, and finally rinsed in sterile water. The surface-sterilized roots were then aseptically sectioned into $1 \mathrm{~cm}$ fragments, distributed onto the isolation media, and incubated at $28^{\circ} \mathrm{C}$ for 2 to 15 days. The only bacterial colonies that developed in the media were separately transferred to fresh media to obtain a pure culture (12).

\section{Preparation of bacterial extract}

Endophytic bacterium was inoculated into $100 \mathrm{ml}$ of sterile nutrient broth and kept at $37 \pm 2^{\circ} \mathrm{C}$ for $24 \mathrm{hrs}$. With continuous shaking. Then $20 \mathrm{ml}$ of grown culture was transferred into $1000 \mathrm{ml}$ of nutrient broth after incubated at $37^{\circ} \mathrm{C}$ for 5 days under continuous shaking at $120 \mathrm{rpm} / \mathrm{min}$ .Mass cultivated cultures were centrifuged and the supernatant was mixed with equal volume of ethyl acetate $(1: 1)$ in a separating funnel and after vigorous shaking, the organic material was collected and subjected for evaporation.

\section{Assay of Antimicrobial Activity}

\section{Test bacteria}

Bacterial pathogens used in the study were obtained from the Culture Collection from ALSadder Hospital in Misan city of Iraq during the year 2015. Include three gram negative bacteria include Escherichia coli, Salmonella typhi,Pseudomonas aeruginosa and three gram positive bacteria include Staphylococcus aureus, Streptococcus pneumonia and Bacillus cereus. The bacteria were maintained in Nutrient agar (NA) and Sabourauds dextrose agar (SDA) slants are used for the maintenance of yeasts. 
Evaluation of Antimicrobial and Antioxidant activity of secondary metabolites isolated from endophytic bacterium Bacillus megaterium isolated from wheat root in Iraq

\section{Rashid Rahim Hateet}

\section{Antimicrobial Activity}

Filter paper discs $(0.6 \mathrm{~mm})$ after being sterilized by autoclave were socked in bacterial crude extract solution for $5 \mathrm{~min}$., filter paper discs with extract were placed on the surface of MullerHinton agar medium in Petri-dishes Plates streaked with $0.2 \mathrm{ml}$ of microbial suspension. Plates were incubated at $37{ }^{\circ} \mathrm{C}$ for $24 \mathrm{hr}$ for bacteria and $48 \mathrm{hr}$ for yeasts an appearance of inhibition zones $(\mathrm{mm})$ around the filter paper disc indicating the bioactivity of crude metabolites of the tested bacterial isolates (13). The diameters of the clear zones were measured and compared with control agar plates containing discs with solvent only (ethyl acetate) as control, triplicates were made.

\section{Minimal inhibitory concentration and minimal bactericidal concentration and Minimal fungicidal concentration test.}

The minimal inhibitory concentration (MIC), minimal bactericidal concentration (MBC) and minimal fungicidal concentration (MFC) values were determined by the standard serial dilution assay (14). Bacterial extract isolate was selected for this test. The inhibitory test was carried out on Muller-Hinton agar medium for bacteria and Sabourauds dextrose agar for yeasts.

\section{Antioxidant activity}

The 2, 2-diphenyl-1-picrylhydrazyl (DPPH) radical scavenging capacity was measured according to (15). $1 \mathrm{ml}$ of bacterial extract was mixed with $0.5 \mathrm{ml}$ of $0.2 \mathrm{mM}$ methanolic DPPH solution. The reaction was allowed to stand at room temperature in the dark for $30 \mathrm{~min}$ and the absorbance was recorded at $517 \mathrm{~nm}$ against a blank(methanol solution).Dilutions were made to obtain concentrations of 1000, 500, 250, 125, 62.5, 31.25, 15.62, 7.81, 3.90 and $1.95 \mu \mathrm{g} / \mathrm{ml}$. Tests were carried out in triplicate. The ability to scavenge the DPPH radical was calculated using the following equation:

Scavenging effect $(\%)=[(\mathrm{A} 0-\mathrm{A} 1) / \mathrm{A} 0] \times 100$, where $\mathrm{A} 0$ and $\mathrm{A} 1$ are the absorbance of the control and the sample, respectively. 
Evaluation of Antimicrobial and Antioxidant activity of secondary metabolites isolated from endophytic bacterium Bacillus megaterium isolated from wheat root in Iraq

\section{Rashid Rahim Hateet}

\section{Toxicity test}

Cytotoxicity of the bacterial secondary metabolites was examined by using human Red Blood Cells (RBC) following a previously described method (16).

\section{Statistical Analysis}

Data were analyzed using Analysis of Variance (ANOVA) between any pair of variables.

\section{$\underline{\text { Results and Discussion }}$}

The growth of one endophytic bacterium named as isolate $B$. megaterium was observed from the cut edge of the surface sterilized root of wheat after $24 \mathrm{hrs}$ on the nutrient agar plates. Considerable growth was observed after 24 hrs and this strain was isolated, grown and subsequently pure culture was maintained on nutrient agar slant as well as in $10 \%$ glycerol at $4^{\circ} \mathrm{C}$. The bacterium was observed to be Gram positive and rod shaped Endospore formation. Based on the results obtained in (Table1) the isolate was identified as B.megaterium.

Table1.Biochemical testes of Bacillus megaterium.

\begin{tabular}{|r|c|}
\hline Biochemical tests & Results \\
\hline Catalase & $+\mathrm{ve}$ \\
\hline Oxidase & $+\mathrm{ve}$ \\
\hline Indole & $-\mathrm{ve}$ \\
\hline MR/VP & $+\mathrm{ve} /$-ve \\
\hline Citrate utilization & $-\mathrm{ve}$ \\
\hline Nitrate reaction & $-\mathrm{ve}$ \\
\hline Urease production & $-\mathrm{ve}$ \\
\hline Triple sugar ion agar & $\mathrm{H}_{2} \mathrm{~S}-\mathrm{ve}$, acid slant \\
\hline
\end{tabular}

The discovery of novel antimicrobial metabolites from endophytes is an important alternative to overcome the increasing levels of antibiotics resistance by plant and human pathogens (17).Endophytes are chemical synthesizer inside plants (18) in additional, they play a role as a selection system for microbes to produce bioactive substances with low toxicity toward higher organisms (19).The antimicrobial activity of the endophytic bacterium B.megaterium was observed against all the tests bacteria. inhibition zones ranged between 16.5-31.0 mm against Gram-Negative Bacteria and ranged between $29.533 .0 \mathrm{~mm}$ against Gram-Positive Bacteria 
Evaluation of Antimicrobial and Antioxidant activity of secondary metabolites isolated from endophytic bacterium Bacillus megaterium isolated from wheat root in Iraq

\section{Rashid Rahim Hateet}

also observed against testes fungi with inhibition zones ranged between 12.5-16.0 mm(Table2) (Figs.1). Endophytes are reported as novel source of antimicrobial compounds (20). Endophytic microorganisms are excellent sources of bioactive natural products that can be use to satisfy demand of pharmaceutical and medical industries ), since a single endophyte may be able to produce a variety of bioactive metabolites (21). MIC and MBC of extract ranged from 3.12$50 \mu \mathrm{g} / \mathrm{ml}$ against bacterial isolates and MIC and MFC ranged between 50.0-100 $\mu \mathrm{g} / \mathrm{ml}$ against test yeasts . the lowest concentration without visible growth was defined as the MIC. (Table.2 , Fig. 1).

Table 2. Growth inhibition zones and MIC and MBC exhibited by the bacterial extract against microbial strain

\begin{tabular}{|c|c|c|c|}
\hline $\begin{array}{c}\text { Gram-Negative } \\
\text { Bacteria }\end{array}$ & Inhibition zones $(\mathbf{m m})$ & $\mathrm{MIC}(\boldsymbol{\mu g} / \mathbf{m l})$ & $\mathrm{MBC}(\boldsymbol{\mu g} / \mathbf{m l})$ \\
\hline E. coli & 30.0 & 6.25 & 12.5 \\
\hline Sal. typhi & 31.0 & 6.25 & 12.5 \\
\hline Ps.aeruginosa & 16.5 & 12.5 & 25.0 \\
\hline $\begin{array}{c}\text { Gram-Positive } \\
\text { Bacteria }\end{array}$ & & & \\
\hline S. aureus & 30.5 & 25.0 & 50.0 \\
\hline $\begin{array}{c}\text { Strep. } \\
\text { pneumoniae }\end{array}$ & 29.5 & 6.25 & 12.5 \\
\hline B. cereus & 33.0 & 3.12 & 6.12 \\
\hline Yeasts & & & $\mathrm{MFC}(\boldsymbol{\mu g} / \mathbf{m l})$ \\
\hline C.albicans & 16.0 & 50 & 100 \\
\hline C.kruzi & 12.5 & 50 & 100 \\
\hline
\end{tabular}

Numbers represent average of three replicates $\mathrm{P} \leq 0.05$ 


\section{DIYALA JOURNAL FOR PURE SCIENCES}

Evaluation of Antimicrobial and Antioxidant activity of secondary metabolites isolated from endophytic bacterium Bacillus megaterium isolated from wheat root in Iraq

\section{Rashid Rahim Hateet}
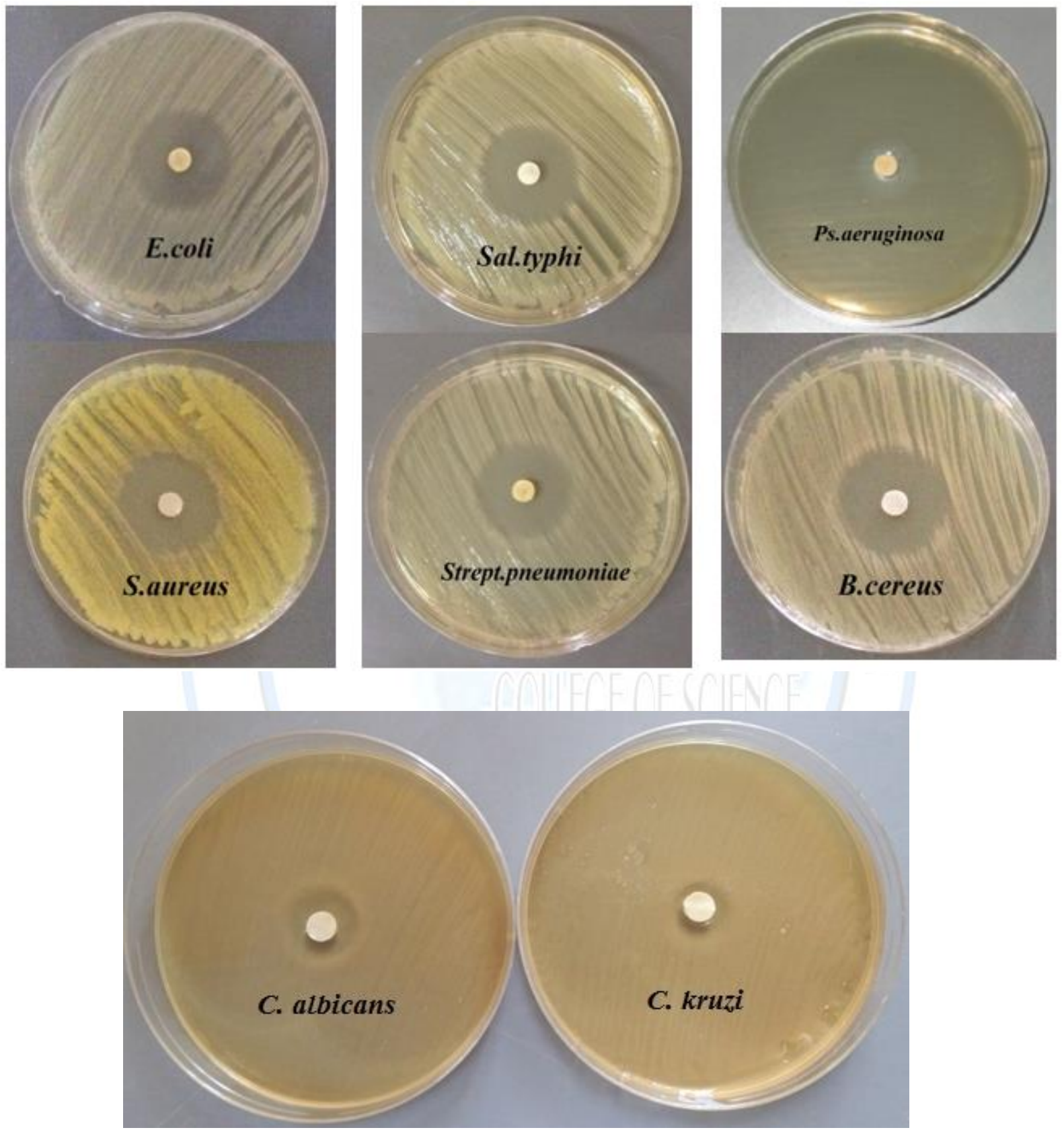

Fig. 1. Inhibition zones exhibited by endophytic bacterium extract against microbial strains 
Evaluation of Antimicrobial and Antioxidant activity of secondary metabolites isolated from endophytic bacterium Bacillus megaterium isolated from wheat root in Iraq

\section{Rashid Rahim Hateet}

A verification of non toxicity of the bacterial extract against human blood revealed a negative test. Antioxidants are compounds that inhibit or delay the oxidation process by preventing the initiation or propagation of oxidizing chain reactions. DPPH radical scavenging assay is a swift and sensitive method for the antioxidant activity. to determination of free radical scavenging activity using the stable 2, 2- diphenyl-1-picryl-hydrazyl radical (DPPH) has received the utmost attention owing to the ease of use and its convenience (Moreno et al., 1998). It was observed that the scavenging activity of secondary metabolites from $B$.megaterium at all concentrations from 1.95 to $1000 \mu \mathrm{g} / \mathrm{ml}$ is rather strong (20-80\%). The extract improved $80 \%$ inhibition at higher concentrations, indicating lesser antioxidant capacity than positive control Figure (2) .

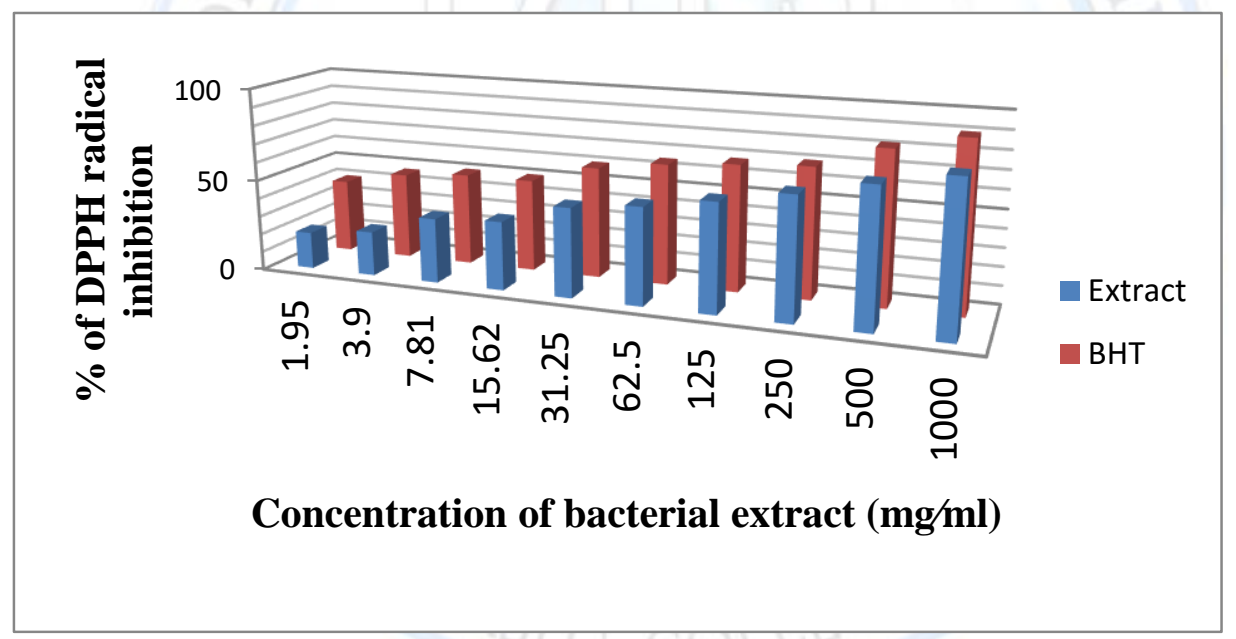

Figure 2:Antioxidant (DPPH scavenging) activity of investigated bacterial extract presented as percentage of DPPH radicals inhibition

\section{Conclusion}

Endophytic bacteria have proven to be rich sources of novel natural compounds with a wide spectrum of biological activities. This study revealed that this endophytic bacterium was showing significant antibacterial, antifungal and antioxidant activity. 
Evaluation of Antimicrobial and Antioxidant activity of secondary metabolites isolated from endophytic bacterium Bacillus megaterium isolated from wheat root in Iraq

Rashid Rahim Hateet

\section{$\underline{\text { References }}$}

1. Asraful, I.S.M; Math, R.K;Kim, J.M;Yun, MG, C. J.J;Kim, E.J;Lee,Y.H andYun, H.D. (2010). Effect of Plant Age on Endophytic Bacterial Diversity of Balloon Flower (Platycodon grandiflorum) Root and Their Antimicrobial Activities. Curr. Microbiol. 61(4):346-356.

2. Trivedi, P;Duan, Y.G and Wang, N. (2010) Huanglongbing, a systemic disease, restructures the bacterial community associated with citrus roots. Appl. Environ. Microbiol. 76(11):3427-3436.

3. Cho, K.M;Hong, S.Y;Lee, S.M; Kim, Y.H;Kahng, G.G;Lim, Y.P;Kim, H and Yun, H.D. (2007) Endophytic bacterial communities in ginseng and their antifungal activity against pathogens .Microb. Ecol. 54(6):341-351.

4. Justin, T.C and Christopher, M. (2003) Isolation and identification of from surfacesterilized wheat roots. Appl. Environ. Microbiol.69(9):5603-5608.

5. Bacon, C. Wand White, J. F(2000)Microbial Endophytes. Marcel Dekker Inc. N.Y. New York.

6. Strobel, G and Bryn Daisy. (2003)Bioprospecting for microbia endophytes and their natural products .Microbiol.Mole. Boil. Rev.67 (4):491-502.

7. Miller, R. V., Miller, C. M., Garton-Kinney, D.,Redgraane, B., Sears, J., Condron, M., Teplow, D and Strobel, G. A.(1998) Isolation of unique antimycotic Ecomycin from Pseudomonas viridiflava.J. App. Microbiol. 84(6):937-944.

8. Strobel, G.A.;Miller, R.V.;Miller, C.;Condron, M.;Teplow, D.B and Hess, W.M. (1999) Cryptocandin, a potent antimycotic from the endophytic fungus Cryptosporiopsis $c f$. quercina. Microbiol, 145(6):1919-1926.

9. Lee ,J.;Lobkovsky, E.;Pliam, N.B.;Strobel, G.A.;Clardy, J and Subglutinols ,A (1995)immunosuppressive compounds from the endophytic fungus Fusarium subglutinans. J. Org. Chem, 60(22):7076-7077.

10. James,H.; Gary,S and Daisy,B.(2004)Natural Products from Endophytic Microorganisms, 67(2):257-268. 
Evaluation of Antimicrobial and Antioxidant activity of secondary metabolites isolated from endophytic bacterium Bacillus megaterium isolated from wheat root in Iraq

\section{Rashid Rahim Hateet}

11. Verma,C.; Vijay, E.; Lobkovsky, C.;Gange, A.;Singh,S. and Prakash, S. (2011) Piperine production by endophyticfungus Periconia sp.Isolated from Piper longum L. TheJournal of Antibiotics, 64(10): 427-431.

12. Gayathri,S.D .S .;Saravanan, M .;Radhakrishnnan,B and Kathiresan, K. (2010).Bioprospecting potential of fast growing endophytic bacteria from leaves of mangrove band salt marshplants. Indian. J. Biotechnol. 9(4): 397-402.

13. Strobel, G.A.; Hess, W.M.; Ford, E .; Sidhu, R.S. and Yang, X.(1996) Taxol from fungal endophytes and issue of biodiversity. J. Ind. Microbiol., 17(6): 417 -423.

14. McGinnis, M. R. (1980). Laboratory Handbook of Medical Mycology, Academic Press, New York.

15. Hatano, T.;Kagawa, H.;Yasuhara, T and Okuda, T.(1988)Two new flavonoids and other constituents in licorice root: their relative astringency and radical scavenging effect. Chem Pharm Bull. 36(6): 2090-2097.

16. Xian-guo, H. and Ursula, M. (1994). Antifungal compound from Solanum nigrescens.J. Enthopharm. 43(4): 173-177.

17. Liu ,X.;Dong ,M.;Chen ,X.;Jiang, M.;Lv ,X and Zhou, J. (2008)Antimicrobial activity of an endophytic Xylaria sp.YX-28 and identification of its compound 7-amino-4methylcoumarin, Applied Microbiology and Biotechnology, 78(2): 241-247.

18. Strobel ,G.A.(2003) Endophytes as sources of bioactive products, Microbes and Infection, 5(6), 535-544.

19. Owen, N.L. and Hundley, N. (2004)Endophytes - the chemical synthesizers inside plants Science Progress, 87, 79-990.

20. Strobel, G. A. and Daisy, B. (2003).Bioprospecting for Microbial Endophytes and Their Natural Products. Microbiol. Mol. Bio. Rev. 67(4):491-502.

21. Ramasamy, K.; Lim ,S.M.; Bakar, H.A.; Ismail, N.; Ismail, M.S.; Ali, M.F.; Weber, J.F.F and Cole, E.(2010) Antimicrobial and cytotoxic activities of Malaysian endophytes. Phytother Res. 24(5): 640-643. 